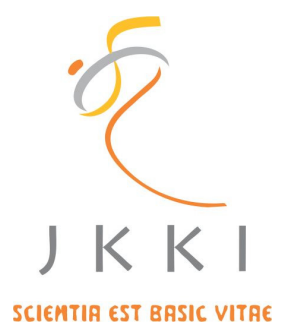

Jurnal Kedokteran dan Kesehatan Indonesia

Indonesian Journal of Medicine and Health

Journal homepage: https://journal.uii.ac.id/JKKI

\title{
Sexual experiences of girls engaged in child marriage: A review of qualitative
}

Farhah Kamilah*1, Elsye Maria Rosa²

${ }^{1}$ Master of Nursing, Universitas Muhammadiyah Yogyakarta, Bantul, Indonesia

${ }^{2}$ Master of Hospital Administration, Universitas Muhammadiyah Yogyakarta, Bantul, Indonesia

Review Article

\begin{tabular}{|c|c|}
\hline & \\
\hline E INFO & \multirow{4}{*}{$\begin{array}{l}\text { Child marriage cases appear to occur in children between } 15 \text { and } 18 \\
\text { years of age. Girls who are forced into marriage show fear of having sex } \\
\text { with their husbands because they are foreign to this situation. Previous } \\
\text { research has shown that child marriage causes trauma to girls due to } \\
\text { forced sexual intercourse. This study aims to explore sexual aspects from } \\
\text { the perspective of married girls. This study uses } 3 \text { databases PubMed, } \\
\text { EbscoHost, and Proquest. The main keywords are "child marriage", "early } \\
\text { marriage", "Sexual", "Experience", and "Qualitative". The search for articles } \\
\text { was carried out in accordance with the guidelines of PRISMA. The findings } \\
\text { were } 5 \text { main themes from } 15 \text { articles. The findings are the desire to have } \\
\text { children soon after marriage, delay of having children, husband and wife } \\
\text { relationship in child marriage, lack of knowledge related to reproductive } \\
\text { health, and powerlessness makes reproductive health decisions. The } \\
\text { problem of the sexual aspect of child marriage makes it difficult for girls to } \\
\text { live their married lives. Girls must quickly adapt to their role as wives and } \\
\text { be able to meet everyone's marriage expectations in general. However, } \\
\text { another case also explains that families and partners understand the } \\
\text { condition of girls who are not ready to face this phase. The views of society } \\
\text { and families build perceptions of child marriage, including the fulfillment } \\
\text { of sexual needs therein. }\end{array}$} \\
\hline rha & \\
\hline Pril 30,2021 & \\
\hline ppyright @2021 A & \\
\hline
\end{tabular}

Kasus pernikahan anak sering terjadi pada anak-anak yang berusia antara 15 dan 18 tahun. Gadis yang dipaksa menikah menunjukkan ketakutan berhubungan seks dengan suaminya karena mereka asing dengan situasi ini. Penelitian sebelumnya menunjukkan bahwa pernikahan anak menyebabkan trauma pada anak perempuan akibat hubungan seksual yang dipaksakan. Penelitian ini bertujuan untuk mengeksplorasi aspek seksual dari perspektif gadis yang sudah menikah. Penelitian ini menggunakan 3 database PubMed, EbscoHost, dan Proquest. Kata kunci utamanya adalah "child marriage", "early marriage", "Sexual", "Experience", dan "Qualitative". Pencarian artikel dilakukan sesuai dengan pedoman PRISMA. Hasil temuan dalam penelitian ini terdapat 5 tema utama dari 15 artikel. Temuan penelitian diantaranya keinginan memiliki anak segera setelah menikah, keterlambatan memiliki anak, hubungan suami istri dalam perkawinan anak, kurangnya pengetahuan terkait kesehatan reproduksi, dan ketidakberdayaan membuat keputusan kesehatan reproduksi. Masalah aspek seksual perkawinan anak menyulitkan anak perempuan untuk menjalani kehidupan pernikahannya. Anak perempuan harus cepat beradaptasi dengan peran mereka sebagai istri dan mampu memenuhi harapan pernikahan setiap orang secara umum. Namun, kasus lain juga menjelaskan bahwa keluarga dan pasangan memahami kondisi anak perempuan yang belum siap menghadapi fase ini. Pandangan masyarakat dan keluarga membangun persepsi tentang perkawinan anak termasuk dalam pemenuhan kebutuhan seksual didalamnya. 


\section{INTRODUCTION}

Child marriage is a global problem that can be found in all regions of the world. Cases in child marriages involve elements of culture, religion, beliefs, and ethnicity so that new cases arise each year. United Nations International Children's Emergency Fund (UNCIEF) shows that in 2018 the number of child marriages in the world reaches 12 billion cases. India is the highest country with an absolute number of child marriages under 18 years with a total of 15.509.000 cases. ${ }^{1}$ Most cases of child marriage tend to occur in children aged $15-18$ years. ${ }^{2}$ However, some cases of child marriage involve a couple with a younger age that is under 15 years. $^{3}$

United Nations International Children's Emergency Fund revealed that marriages that involve children tend to be more vulnerable to economic problems and health problems, especially on reproductive health in women. At the age of 15-18 years, children are experiencing sexual growth physically and psychologically. ${ }^{4}$ Sexual maturity that has not yet reached the maximum stage makes children unprepared in carrying out the process of marriage at the age of 18 years. Some cases of child marriage occur because of coercion from families, including parents. ${ }^{5}$

The marriage that was forcibly carried out on a girl gave rise to an un-harmonious relationship between a girl and her husband. This happens because the daughter has difficulty establishing communication with her husband and understands her new role as a wife. ${ }^{6}$ Girls feel confused about meeting the needs of their marriage, especially sexual needs. Girls who experience forced marriages tend to not be ready to face sexual needs in marriage. ${ }^{7}$ Girls who are forced to marry experience fear of having sexual relations with their husbands due to feelings of stress in undergoing the marriage. ${ }^{8}$ Some cases of child marriage cause trauma to girls due to forced sexual relations with their husband and physical abuse if they do not fulfils their husband's wishes. ${ }^{9}$ This problem leads to the question of how is the experience of girls in sexual aspects of child marriage? This review aims to answer this question through a literature study relating to sexual experiences in child marriage, especially in girls. Specifically, the aim of this review is to explore the experience of girls' sexual aspects during marriage. This information will provide insights for health workers and the community to help married women deal with sexual problems.

\section{METHODS}

The articles included in the review were articles on the experiences of married women under the age of 18 years. This review will discuss articles that use qualitative methods with a variety of approaches, such as descriptive, phenomenology, case reports, ethnography, and grounded theory. The article used is a research study on the sexual aspects of child marriage. The sexual aspect of this review is the sexual experience of girls in their marriage. The discussion involves physical and emotional experiences of the sexual aspects directly experienced by girls. These reviews are not limited to a specific region or country and take place in a community or health centre.

\section{Literature search methods}

The literature search in this study used three electronic databases PubMed, Proquest, and Ebsco. The main keywords used in this review are "child marriage", "early marriage", "Sexual", "Experience", and "Qualitative". Keywords are developed using "OR" and "AND". The articles used are articles published in 2015-2019. This study examines cases of child marriage during the last five years in order to see the origin of child marriage and the social implications of child marriage which is currently developing due to social values, attitudes, and culture in society related to sexual aspects. The articles are in English only, full text, and discuss topics related to the sexual experiences of girls undergoing marriage. The exclusion criteria in this study were articles that did not contain research ethics, articles that did not discuss the method in detail, and articles that did 
not specifically discuss sexual aspects. In this review, five (5) steps are used in the search for literature. The first step is formulation. This step is done by developing keywords by trying various keywords related to the objectives of the research. The second step is identification; in this stage, the search is done by using keywords that have been determined and limit the search by including the year, language used, and full text, 1.551 articles were found at this stage of the search. The third step is selection, where the article is excluded based on the title and abstract. At this stage, 114 articles were found and excluded. The four step is charting; the articles that are already collected will be re-read thoroughly by researchers, and articles that do not support the review will be excluded. The results of filtering the articles from charting at this stage were 42 articles. Lastly, in the fifth step, the article was carried out critical appraisal using tools from Joanna Briggs Institution (JBI) to assess the quality of the article. The final result at the last stage was 15 articles (Figure 1).
Formulation Review Questions

\section{Identification}

Selection

Collating, Summarizing

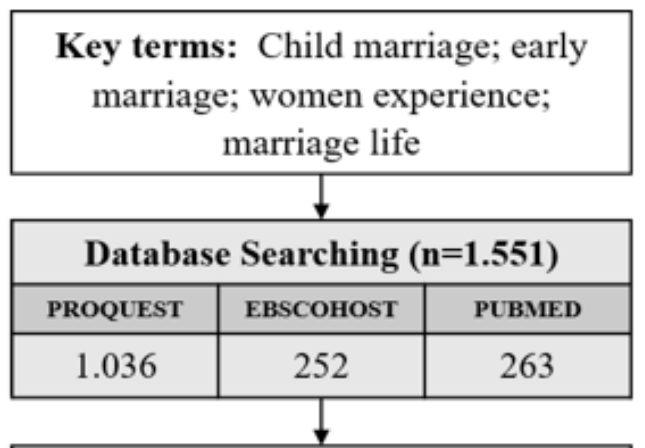

\begin{tabular}{|c|c|c|}
$\begin{array}{c}\text { Articles with appropriate titles and } \\
\text { abstracts (n=114) }\end{array}$ \\
\hline PROQUEST & EBSCOHOST & PUBMED \\
\hline 70 & 21 & 23 \\
\hline
\end{tabular}

Duplicate: 9

Not Full Text: 10

Not discussing from the women perception: 15

Not discussing from women who are married under 18 year old: 8

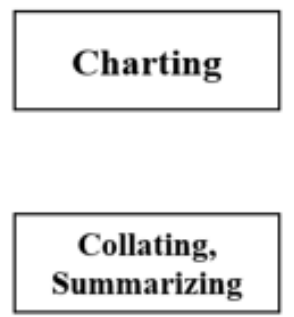

The results are not clearly described: 27

\section{DATA ANALYSIS}

This review uses thematic analysis in analysing data. Thematic analysis is an analytical method used to identify and organize systematic 
insights into patterns of meaning (themes) in a whole set of data. ${ }^{10}$ The data obtained will be grouped, categorized, and summarized to form a systematic conclusion to answer the research problem in this review. In the thematic analysis, five steps are carried out, namely (Figure 2):

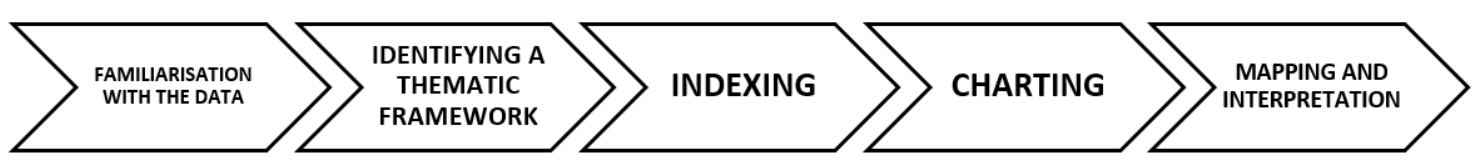

Figure 2. Steps of thematic analysis

First step is familiarisation with the data. This step begins with the introduction of data to review and note recurring themes throughout the entire article. Second step is identifying a thematic framework. The author creates a framework adapted from emerging themes based on the analysis at this stage. The framework provides a detailed list of girls' experiences of child marriage. Third step is indexing. At this step, two authors review information independently and look for themes that fit the framework. If additional themes emerge, the framework is revised according to the agreement of the entire writing team. The entire article is read until it does not bring up a new theme. Coding is based on themes identified in the data related to the themes of the framework. In one study can be indexed using one or more codes. Fourth step is charting. This step makes the data that has been obtained sorted by theme and presented in the form of an analysis table. The table illustrates the studies and themes making it easier to compare study findings across different themes and sub-themes. Fifth step are mapping and interpretation. This step presents the data in graphical form to make it easier to define concepts. Furthermore, the data are described in detail including the relationship between themes that lead to the objectives of the study so that a better understanding of women's experiences in sexual, maternal and maternal aspects can be found in child marriage. After finding the theme, we looked at the relevance of the themes by looking at the similarities in words in each theme. The entire data analysis process is assisted by the NVIVO 12 Plus application.

\section{RESULTS}

A Several studies have been conducted to explore the experience of girls in marriage. Results of the search identified 15 articles., ${ }^{5,11-23}$ The articles are from Jordan (1), Malaysia (1), Nepal (1), Niger \& Ethiopia (2), Iran (3), Thailand \& Myanmar (1), Ethiopia (1), Ethiopia \& India (1), India (1), Bangladesh (3). In the 15 articles analysed, 5 main themes represent the condition of girls in dealing with marriage on the sexual aspect.

A review of 15 articles produced 5 main themes related to the sexual aspects of child marriage, as shown in Figure 3. The themes found have a relationship between one theme and another. This relationship can be seen from the word similarity shown in Table 2 .

In the sexual aspect of girls who experience child marriage, the desire to have children soon has a close relationship with the obligation to have children with a correlation value of 0.846 . Then followed by the link between the mental and physical unpreparedness of girls with the delay of having children (0.718), the desire to have children immediately with the fear of losing their husbands (0.594), the desire to have children immediately with the fertility of girls (0.581), and the obligation to have children with powerlessness to make reproductive health decisions (0.507). 
Table 1. Characteristics of the included studies

\begin{tabular}{|c|c|c|c|c|}
\hline $\begin{array}{l}\text { Author (Year) \& } \\
\text { Country }\end{array}$ & $\begin{array}{c}\text { Phenomenon of } \\
\text { interest }\end{array}$ & Research design & Sample & Findings \\
\hline $\begin{array}{l}\text { Al-Kloub, M. I., Al-Zein, } \\
\text { H. J., Abdalrahim, M. S., } \\
\text { \& Abed, M. A (2019)7 } \\
\text { Country: Jordan }\end{array}$ & $\begin{array}{l}\text { The Experience } \\
\text { of marriage and } \\
\text { motherhood among } \\
\text { young Jordanian } \\
\text { women with a first- } \\
\text { born child }\end{array}$ & $\begin{array}{l}\text { D e s c r i p ti v e } \\
\text { qualitative using } \\
\text { semi-structured } \\
\text { interviews }\end{array}$ & $\begin{array}{l}15 \text { young } \\
\text { mothers who } \\
\text { gave birth } \\
\text { before than } 19 \\
\text { years }\end{array}$ & $\begin{array}{l}\text { The responsibilities of marriage } \\
\text { and motherhood take the lives } \\
\text { of adolescent girls. In-laws } \\
\text { arrange married life when girls } \\
\text { and spouses cannot support } \\
\text { themselves }\end{array}$ \\
\hline $\begin{array}{l}\text { Kohno, A., Dahlui, M., } \\
\text { Nik Farid, N. D., Ali, } \\
\text { S. H., \& Nakayama, T. } \\
\text { (2019)5 } \\
\text { Country: Malysia }\end{array}$ & $\begin{array}{l}\text { The reason for child } \\
\text { marriage in Kelantan, } \\
\text { Malaysia is related to } \\
\text { individual, family and } \\
\text { community issues }\end{array}$ & $\begin{array}{l}\text { Qualitative using } \\
\text { semi-structured } \\
\text { interviews }\end{array}$ & $\begin{array}{l}18 \text { women }(18 \\
-44 \text { years) who } \\
\text { married before } \\
18 \text { years }\end{array}$ & $\begin{array}{l}\text { Child marriages that occur } \\
\text { due to poor decision-making, } \\
\text { family poverty, and religious } \\
\text { and cultural norms. }\end{array}$ \\
\hline $\begin{array}{l}\text { Maharjan, B., Rishal, } \\
\text { P., \& Svanemyr, J. } \\
\text { (2019)11 } \\
\text { Country: Nepal }\end{array}$ & $\begin{array}{l}\text { The experience of } \\
\text { adolescent girls in the } \\
\text { awareness of seeking } \\
\text { maternal health care }\end{array}$ & $\begin{array}{l}\text { Ex p l o r a to ry } \\
\text { qualitative using } \\
\text { semi-structured } \\
\text { interviews and } \\
\text { Focus Group } \\
\text { Discussions (FGD) }\end{array}$ & $\begin{array}{l}13 \text { women who } \\
\text { were married } \\
\text { before } 18 \\
\text { years and had } \\
\text { one child or } \\
\text { were pregnant } \\
\text { during the } \\
\text { interview }\end{array}$ & $\begin{array}{l}\text { Women who marry early are } \\
\text { more prone to risky pregnancies } \\
\text { because of the pressure to give } \\
\text { birth early, limited autonomy, } \\
\text { and little knowledge about } \\
\text { reproductive health issues }\end{array}$ \\
\hline
\end{tabular}

Neetu A. John, Jeffrey The psychological Mixed methods Edmeades, and Lydia health of girls in with qualitative Murithi (2019)12 dealing with child data collection Country: Niger \& marriage Ethiopia

Neetu A. John, Jeffrey The quality of Mixed methods Edmeades, and Lydia child marriage with qualitative Murithi (2019)13 relationships in data collection Country: Niger \& Ethiopia using semiEthiopia

s tru ctured interviews and Focus Group Discussions (FGD)

Tirgari, B., Rayyani, The experience of Qualitative using M., Cheraghi, M. A., \& Iranian Teen Mothers Mangeli, M. (2019)14 with parenting Stress. Country: Iran

Asnong, C., Fellmeth, Experiences and Qualitative using G., Plugge, E., Wai, N. perceptions about semi-structured S., Pimanpanarak, pregnancy in interviews and M., Paw, M. K., refugee and migrant Focus Group Charunwatthana, P., communities on Discussions(FGD) Nosten, F., \& McGready, the Thai-Myanmar R. (2018)15 border.

Country: Thailand \& Myanmar

Ketema, H., \& Erulkar, A. (2018)16 Country: Ethiopia interviews

The experiences Qualitative usin and perceptions of semi-structured married girls in family interviews
32 married girls of coercion and children are charged with marital responsibilities, especially sexual demands from partners.

32 married girls

The lack of the role of girls in the selection of partners and the time of marriage, unpreparedness to have sex at marriage, and the reduced agency experienced by women in general in this marriage. planning
18 Iranian teen mothers

Early mother often gets various pressures that threaten the mental health of adolescent mothers.

20 teenagers are pregnant in refugee camps

Important themes are premarital sex, forced marriage, out of school, fear of giving birth, financial insecurity, support structures and domestic violence.

16 women aged Spouse consent is a major 18-24 who determining factor in the use married before of family planning in girls. the age of 18 lack of contraception, dropping 
McClendon, K. A., The barriers and McDougal, L., Ayyaluru, facilitators in the use S., Belayneh, Y., Sinha, of family planning in A., Silverman, J. G., \& married girls include Raj, A. (2018)17 their marital decisionCountry: Ethiopia \& makers India

Mardi, A., Ebadi, Factors that Esmaelzade saeieh, contraception from interviews S., \& Behboodi the perspective of (2018)18

Country: Iran

Ghosh, S., Lahiri, S., \& The experience Datta, N. (2017)19 of well-being and Country: India happiness of young women in rural Bengal with emphasis on their marriage life

Montazeri, S., The views of married Gharacheh, M., girls towards child Mohammadi, N., marriage

Alaghband Rad, J., \& Eftekhar Ardabili, H. (2016)20

Shahabuddin, A., Behaviour in seeking Nöstlinger, C., Delvaux, care during their T., Sarker, M., Delamou, pregnancy, during A., Bardají, A., Broerse, labor, and postpartum J. E. W., \& De Brouwere, in adolescent married V. (2019)21 girls

Country: Bangladesh A., Shahbazi, S., influence the use of semi-structured Mogh a d a m, Z. married girls Country: Iran
Qualitative using 128 married semi-structured women interviews

aged 13-19

years who have married and come to urbanrural healthcare centers in Ardabil

Qualitative using semi-structured interviews

654 married women aged 13-24 years in three districts in West Bengal

Qualitative using semi-structured interviews

15 married aged 13-19 years

30 married teenage girls from three Upazilas (Sub districts) of Rangpur district teenage girls

The vulnerability of young women with regard to reproductive control, and support of the need for a multisectoral

Not using contraception because of lack of knowledge about contraception, pressure to get pregnant and misconceptions affect their decision not to use contraception.

Child marriages are arranged by parents and girls do not know who they are married to. Girls have difficulty adapting to married life.

Girls are not ready for early marriage. Three categories emerge related to "family structure," "low autonomy decision making," and "response to needs."

Girls' perceptions, their lack of knowledge about maternal and reproductive health, certain traditional practices, their sole dependency on their husbands and mothers-in-laws, and their low decision-making autonomy towards their own health care negatively influenced their utilization of skilled maternal health services.

Shahabuddin, A. S. Factors affecting the M., Nöstlinger, C., decision-making Delvaux, T., Sarker, M., process of married Bardají, A., Brouwere, young women in V. D., \& Broerse, J. E. W. connection with the (2016)22

Country: Bangladesh use of contraceptive methods and childbearing

Henry, E. G., Lehnertz, Social and cultural N. B., Alam, A., Ali, N. factors that exist in A., Williams, E. K., girls who are married Rahman, S. M., Ahmed, in determining the S., El Arifeen, S., Baqui, time of marriage and A. H., \& Winch, P. J. first birth (2015)23

Country: Bangladesh
Qualitative using semi-structured interviews and Focus Group Discussions (FGD)

35 married young women

Teenage girls show weakness in decision making about the use of contraception and methods give birth. The main decision is taken by her husband or mother-in-law.

Qualitative using 80 newly semi-structured married girls interviews
Public perception that delaying first birth after marriage can cause infertility, embarrassing the family, and in some cases directing the husband's family to find another wife for their son. 
Table 2. Result of cluster anlysis (word similarity)

\begin{tabular}{|c|c|c|}
\hline Cluster A & Cluster B & $\begin{array}{l}\text { Word } \\
\text { Similarity }\end{array}$ \\
\hline The desire to have children soon & Obligation to have children & 0.846 \\
\hline Mentally and physically unprepared & Delay in having children & 0.718 \\
\hline The desire to have children soon & Fear of losing their husband & 0.594 \\
\hline The desire to have children soon & Girls infertile & 0.581 \\
\hline Obligation to have children & Decision making related to reproduction health & 0.507 \\
\hline $\begin{array}{l}\text { Decision making related to reproduction } \\
\text { health }\end{array}$ & Contraception can cause infertility in girls & 0.457 \\
\hline The desire to have children soon & Delay in having children & 0.450 \\
\hline The desire to have children soon & Mentally and physically unprepared & 0.384 \\
\hline
\end{tabular}

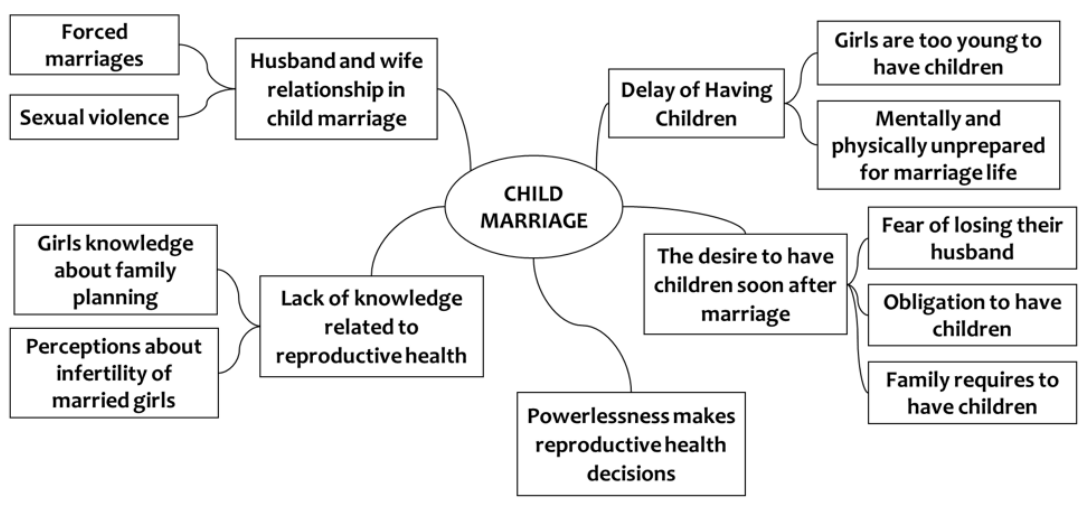

Figure 3. Findings themes

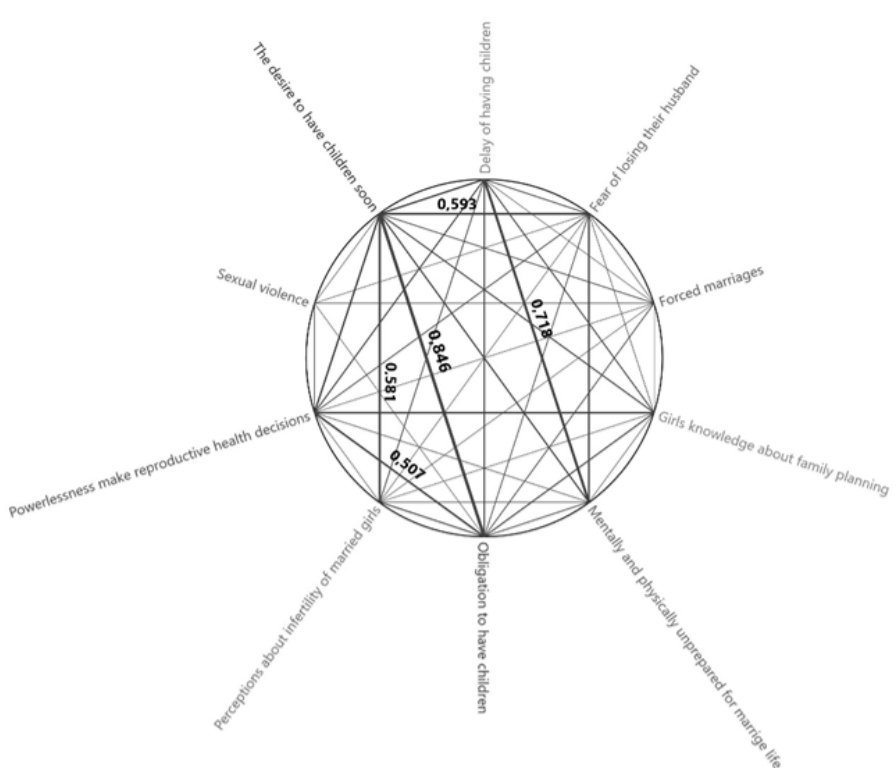

Figure 4. Cluster analysis of sexual aspect 


\section{Delay of Having Children \\ Girls are too young to have children \\ Girls who experience child marriage experience feelings of worry when they think of moments when they have children.7,12,15,16,18 The desire to return to school is the reason for girls to postpone having children. ${ }^{12,16}$ Readiness in finance and health is also a reason for girls and partners to postpone pregnancy in the first years of marriage.,16,18 \\ "I don't want a baby right now. I am still very young and this is not an appropriate age to give birth to a child".15}

\section{Mentally and physically unprepared for marriage life}

Girls experience fear in the face of child marriage. ${ }^{12,15,19,20}$ They feel too young to live a married life. ${ }^{15,21}$ They are not ready to develop responsibilities as a wife or mothers. ${ }^{12,15,20,21}$

"Ifyou get married at a very young age, then your body is not physically fit and mature enough to have a child".15

\section{Husband and wife relationship in child marriage \\ Forced marriages}

Forced marriages cause feelings of anxiety and fear in girls in the face of married life. $5,16,22-23$

"I was depressed and cried all the time...

How do you think it feels to be forced into a marriage and a life with someone you didn't choose or know?"23

They felt they did not know the nature and character of the man who was her husband. ${ }^{16,23}$ However, they must spend the rest of their lives with these men.

\section{Sexual violence}

Sexual violence against girls who experience child marriage occurs because of the refusal of girls to have sexual relations with her husband Girls are forced to serve their husbands under any circumstances. The husband also does not hesitate to physically hurt if his wife does not fulfil his wishes. ${ }^{12,13}$
"It used to be so painful for me when we had intercourse. But I couldn't tell that to anyone. And when I refused him, he used to beat me, splash water on me, put a rock on me and he waited till I got tired and took me afterwards... I wished I was dead".13

\section{Lack of knowledge related to reproductive} health

\section{Perceptions about infertility of married} girls

At child marriage, girls experience great stress in terms of fertility. ${ }^{13,17,19}$

"If you have a baby in the year of your marriage, then the villagers will not say anything bad about you. But if two or three years pass without a baby, then they will call you banja [slang term for an infertile woman] or atkura [slang term for an infertile man]. So, you could avoid all of this gossip if you have a child soon after marriage."17

Girls who do not have children at the beginning of the marriage year are considered infertile women. ${ }^{13}$ The family and the environment will talk bad things about her because they are considered useless as a wife for her husband..$^{13,17}$

\section{Girls knowledge about family planning}

Girls who experience child marriage consider using contraception to cause infertility. $7,11,13,14,16$ "Currently I don't use any kind of contraceptives because my mother-in-law said it is not good to use contraceptives after the first baby because they may cause infertility"'

This information is obtained from the mother-in-law or elder woman and is considered experienced in the environment. ${ }^{11,14}$ Thus, many girls do not use contraception after marriage even though they have not been advised to conceive because of their young age. ${ }^{7,13}$

\section{Powerlessness makes reproductive health decisions}

In child marriage, girls do not have the power to make decisions regarding reproductive 
health. $^{2-9}$ The life of a girl after marriage is regulated by her husband or mother-in-law so that decisions are made based on the agreement between husband and mother-in-law. ${ }^{7,11,12}$

"Early marriage has consequences, take away your rights, your personality is nothing, you are controlled by in-laws. When you are aware time is over and you can't change anything, you want respect, but it is not achievable".

Decisions regarding the use of family planning, reproductive health checks, pregnancy, until birth must be based on the consent of the husband or mother-in-law husband. ${ }^{7,11-16}$ Girls must follow the decision and must not say no to the decision. ${ }^{12,16}$

\section{The desire to have children soon after marriage}

\section{Family requires to have children}

A married girl experiences a moment where she feels she wants a child. ${ }^{11-14,16,17}$ This desire arises because of the encouragement of the husband to immediately have children after marriage. . $^{14,16}$

"Usually, the first baby is born within [the] first year of marriage. The in-laws won't like it if we say that she will get married now but will not bear a child for [the] next 3-4 years or so."14

Also, encouragement from in-laws motivates girls to get pregnant even though they are under 20 years old. ${ }^{12}$ Acceptance from the husband's family is a reason for girls to have children soon. ${ }^{12,13,17}$

\section{Obligation to have children}

At child marriages, girls have the perception that the role of a wife is to give children. ${ }^{12-14,16,17}$ Girls are obliged to give children as a form of their responsibilities as a wife. . $^{12,17}$

"Many simply believed that it was the responsibility and role of newly married girls to bear children".12

The birth of a child in married life is a moment that is required, at least once. ${ }^{12,14}$

\section{Fear of losing their husband}

A married girl feels afraid that her husband will switch to another woman if he cannot carry out his duties as a wife. ${ }^{11,14,17}$

"I was scared. If I did not get pregnant, my husband's family would force my husband to marry another girl, even if he did not divorce me. Also, I thought that perhaps my husband's family members would love me for the sake of the child".11

The most dominant fear occurs when she is unable to meet her husband's sexual needs. ${ }^{11,17}$ So that girls are willing to meet their husband's sexual needs even though he feels not ready to do that. ${ }^{11,14,17}$

\section{DISCUSSION}

The results of the review show that there are several conditions related to unpleasant sexual experiences for married girls. In child marriage, girls have the desire to have children in the first year of marriage. One of the reasons that reinforces this desire is the perception of women who think that married women should immediately give birth to children. The husband also has high hopes for his wife to have children in the first years of marriage. For husbands, one of the goals of marriage is to have children. Children are things that must be owned in a marriage relationship. Children are also things that can make girls accepted by the husband's family, especially mother-in-law. ${ }^{6,26}$ The pressure given by the mother-in-law to have children immediately makes girls feel that children are the main key in building a good relationship between themselves and their mother-in-law. Girls are of the view that the job she has to do as a wife is to have children immediately and that is her duty. In some cases, girls who are married do not care about their safety due to pregnancy at a young age (under 18 years). ${ }^{27}$ The condition of young girls who have to experience pregnancy often causes health problems during pregnancy. Severe anemia is often experienced by pregnancies with 
mothers under 18 years of age. ${ }^{26,27}$ The risk of eclampsia and bleeding is also high in mothers who conceive at the age of under 18 year. ${ }^{30,31} \mathrm{In}$ addition, their knowledge about reproduction and maternal health is still low, so they are often unable to take care of themselves and the fetus during pregnancy. ${ }^{32}$ They only focus on having children immediately after marriage. The stigma that exists in society makes them claim to be useful wives after having children.

In some cases, girls who marry at a young age have feelings of fear of the stigma of society because they are considered infertile if they do not have children immediately after marriage. They consider their young age as a productive age and easy to get pregnant so it is very unnatural when they do not get pregnant. ${ }^{27,33}$ When they didn't get pregnant in the first year of marriage, the neighbors would talk badly about them and call them barren women. Culture that develops in society makes girls have the same perception and claim themselves to meet the expectations of their environment. This condition often puts pressure on girls. Psychologically, the condition of married girls has put a lot of pressure on them because they have to adapt to their new role as partners. ${ }^{34}$ The pressure is getting bigger when a girl has to have a child immediately because she has to re-adapt to her role as a partner and mother. ${ }^{2,25}$ This condition often causes girls to be unable to carry out their role in the family optimally. ${ }^{35}$ Depressed girls also often feel unhappy with their married life.

The powerlessness of girls is also felt when girls cannot independently decide their own needs. Girls do not have the right to decide what is best for themselves, including decisions about reproductive health. married girls are considered to have become husbands so that all decisions tend to be made by their partners. In child marriage, girls are considered as unsuitable people to make decisions in the family. Girls who get married tend to drop out of school so they have low education and decisions made are considered not a good choice for families. ${ }^{32,36}$ Decisions in the family will be taken by the husband or mother-in-law. The decision to have children is also the decision of the husband and mother-in-law. In the use of family planning, the role of the husband is very large in decision making. ${ }^{37}$ Husbands are also the main decision makers regarding the right time to have children. The decision taken by the husband is absolute and is considered the best decision for a young wife. ${ }^{37,38}$ In making decisions, the mother-in-law has a considerable influence on the decisions that will be taken by the husbands. Decisions that have been taken must be obeyed by the wife, even if it is against the wishes of the wife. ${ }^{39}$ Girls cannot say 'no' to decisions made by their husbands. ${ }^{9,38}$ They also often feel afraid of the demands of the roles they have to do. The greatest fear often arises when they want to have children but are not ready to have sex with their partner.

Married girls consider themselves too young to have sexual relations with their partners. They also consider themselves unable to conceive and have children at their young age. The development of a girl is physically immature to accept pregnancy, so sexual intercourse is not recommended.$^{32}$ However, due to marriage, girls have an obligation to be able to meet the sexual needs of their partners and the demands of having children. This condition often makes them feel difficult because they are afraid that they will not be able to meet these needs. The reluctance of girls to have sexual relations also occurs when the marriage is an enforced marriage ${ }^{36}$ They do not know their husbands and are often married to men who are much older. Girls who are younger (under 15 years) often do not know anything about sexual relations and feel embarrassed to talk to their husbands. ${ }^{36,40}$ They consider it a taboo thing. This condition often raises the attitude of rejection by girls towards their partners. Rejection by girls often triggers quarrels that lead to physical violence by the husband..$^{37,41,42}$ Husbands often accuse them of not wanting to have children and having affairs with other men when they don't want to have sexual relations. This condition makes the wife worry that her husband will look for other women or even divorce them. The people around them will also encourage their husbands 
to look for other women who are able to meet their sexual needs and provide children. This indirectly forces girls to want to fulfill their partner's sexual needs. This compulsion causes girls to feel unhappy and regret it.

However, not all girls who experience child marriage have this experience. Some cases of child marriage also mention that mental and physical unpreparedness is a strong reason for girls to postpone pregnancy. ${ }^{3}$ Pregnancy delays occur because girls still want to continue their education until completion. ${ }^{30}$ They still do not want their teenage life to be thoroughly embraced by the presence of children at a young age. They feel they still have to adjust themselves to their new duties as a wife and spend their time getting to know their husbands. ${ }^{43}$ Girls also feel that they will not be ready to carry out their roles simultaneously as a wife, mother, and student at the same time. ${ }^{37}$ Besides, the girl also feels that she does not know anything about the process of pregnancy and childbirth, so she feels not ready to care for the child in the first year of marriage ${ }^{24}$ Girls also feel physically unprepared to face pregnancy at a young age. Some girls also experience health problems that require them to postpone pregnancy based on doctor's advice. The doctor communicates the condition of the daughter to the husband so the husband allows the daughter to postpone the pregnancy.

\section{CONCLUSION}

The conditions of child marriage cannot be generalized as a whole in all cases. The influence of values, norms and culture in society gives a different perspective in each case. The sexual experience of married girls is also related to the conditions and perceptions of the community in the area. Several cases stated that the stigma from family and society puts a burden on girls regarding fulfilling sexual needs and the urge to have children. The problem of the sexual aspect of child marriage makes it difficult for girls to live their married lives. Girls must quickly adapt to their role as wives and be able to meet everyone's marriage expectations in general. However, another case also explains that families and partners understand the condition of girls who are not ready to face this phase. So, it can be concluded that the views of society and families build perceptions of child marriage, including the fulfillment of sexual needs therein.

\section{CONFLICT OF INTEREST}

There is no conflict of interest.

\section{ACKNOWLEDGEMENT}

This research received no specific grant from public, commercial or non-profit funding agencies.

\section{REFERENCES}

1. Brides GN. Atlas. Girls Not Brides. [cited 2020 Jan 29]. https://www.girlsnotbrides. org/where-does-it-happen/atlas/

2. Chu MS, Park M, Kim JA. First childbirth experience of international marriage migrant women in South Korea. Women and Birth: Journal of the Australian College of Midwives. 2017;30(4):e198-206.

3. Adedokun O, Adeyemi O, Dauda C. Child marriage and maternal health risks among young mothers in Gombi, Adamawa State, Nigeria: Implications for mortality, entitlements and freedoms. African Health Sciences. 2017;16(4):986.

4. Shrestha RB. Premarital Sexual Behaviour and its Impact on Health among Adolescents. Journal of Health Promotion. 2019;7:43-52.

5. Kohno A, Dahlui M, Nik Farid ND, Ali SH, Nakayama $\mathrm{T}$. In-depth examination of issues surrounding the reasons for child marriage in Kelantan, Malaysia: A qualitative study. BMJ Open. 2019;9(9):e027377.

6. Dean L, Obasi A, El Sony A, Fadul S, El Hassan $\mathrm{H}$, Thomson $\mathrm{R}$, et al. "He is suitable for her, of course he is our relative": A qualitative exploration of the drivers and implications of child marriage in Gezira State, Sudan. BMJ Global Health. 2019;4(3):e001264.

7. Al-Kloub MI, Al-Zein HJ, Abdalrahim MS, Abed MA. Young women's experience of adolescent marriage and motherhood in Jordan. Culture, Health \& Sexuality. 2019;21(4):46277. 
8. Sabbe A, Oulami H, Hamzali S, Oulami N, Le Hjir FZ, Abdallaoui M, et al. Women's perspectives on marriage and rights in Morocco: Risk factors for forced and early marriage in the Marrakech region. Culture, Health \& Sexuality. 2015;17(2):135-49.

9. Braun V, Clarke V. Thematic analysis. In: Cooper H, Camic PM, Long DL, Panter AT, Rindskopf D, Sher KJ, editors. APA handbook of research methods in psychology, Vol 2: Research designs: Quantitative, qualitative, neuropsychological, and biological. Washington: American Psychological Association; 2012. p. 57-71.

10. Maharjan B, Rishal P, Svanemyr J. Factors influencing the use of reproductive health care services among married adolescent girls in Dang District, Nepal: A qualitative study. BMC Pregnancy Childbirth. 2019;19(1):152.

11. Henry EG, Lehnertz NB, Alam A, Ali NA, Williams EK, Rahman SM, et al. Sociocultural factors perpetuating the practices of early marriage and childbirth in Sylhet District, Bangladesh. International Health. 2015;7(3):212-7.

12. John NA, Edmeades J, Murithi L. Child marriage and psychological well-being in Niger and Ethiopia. BMC Public Health. 2019;19(1):1029.

13. John NA, Edmeades J, Murithi L, Barre I. Child marriage and relationship quality in Ethiopia. Culture, Health \& Sexuality. 2019;21(8):853-66.

14. Tirgari B, Rayyani M, Cheraghi MA, Mangeli M. Experiences of Iranian teen mothers with parenting stress: A qualitative study. Comprehensive Child Adolescent Nursing. 2019;1-14.

15. Asnong C, Fellmeth G, Plugge E, Wai NS, Pimanpanarak M, Paw MK, et al. Adolescents' perceptions and experiences of pregnancy in refugee and migrant communities on the Thailand-Myanmar border: A qualitative study. Reproductive Health. 2018;15(1):83.

16. Ketema H, Erulkar A. Married adolescents and family planning in rural Ethiopia: Understanding barriers and opportunities. African Journal of Reproductive Health.
2018;22(4):26-34.

17. McClendon KA, McDougal L, Ayyaluru S, Belayneh Y, Sinha A, Silverman JG, et al. Intersections of girl child marriage and family planning beliefs and use: Qualitative findings from Ethiopia and India. Culture, Health \& Sexuality. 2018;20(7):799-814.

18. Mardi A, Ebadi A, Shahbazi S, Esmaelzade saeieh S, Behboodi Moghadam Z. Factors influencing the use of contraceptives through the lens of teenage women: A qualitative study in Iran. BMC Public Health. 2018;18(1):202.

19. Ghosh S, Lahiri S, Datta N. Understanding happiness and psychological wellbeing among young married women in rural India. Journal of Comparative Family Studies. 2017;48(1):113-31.

20. Montazeri S, Gharacheh M, Mohammadi N, Alaghband Rad J, Eftekhar Ardabili H. Determinants of early marriage from married girls' perspectives in Iranian setting: A qualitative study. Journal of Environmental and Public Health. 2016;2016:1-8.

21. Shahabuddin A, Delvaux T, Nöstlinger C, Sarker M, Bardají A, Sharkey A, et al. Maternal health care-seeking behaviour of married adolescent girls: A prospective qualitative study in Banke District, Nepal. Vidler M, editor. PLoS One. 2019;14(6):e0217968.

22. Shahabuddin ASM, Nöstlinger C, Delvaux T, Sarker M, Bardají A, Brouwere VD, et al. What Influences adolescent girls' decision-making regarding contraceptive methods use and childbearing? A qualitative exploratory study in Rangpur District, Bangladesh. Anglewicz P, editor. PLoS One . 2016;11(6):e0157664.

23. Sámano R, Martínez-Rojano H, Robichaux D, Rodríguez-Ventura AL, Sánchez-Jiménez B, de la Luz Hoyuela M, et al. Family context and individual situation of teens before, during and after pregnancy in Mexico City. BMC Pregnancy Childbirth. 2017;17(1):382.

24. Patra S. Motherhood in childhood: Addressing reproductive health hazards among adolescent married women in India. Reproductive Health. 2016;13(1):52.

25. Austrian K, Soler-Hampejsek E, Duby Z, 
Hewett PC. "When he asks for sex, you will never refuse": Transactional sex and adolescent pregnancy in Zambia. Studies in Family Planning. 2019;50(3):243-56.

26. Wahi A, Zaleski KL, Lampe J, Bevan P, Koski A. The Lived experience of child marriage in the United States. Social Work in Public Health. 2019;34(3):201-13.

27. Yaya S, Odusina EK, Bishwajit G. Prevalence of child marriage and its impact on fertility outcomes in 34 sub-Saharan African countries. BMC International Health Human Rights. 2019;19(1):33.

28. Korenčan S, Pinter B, Grebenc M, Verdenik I. The Outcomes of pregnancy and childbirth in adolescents in Slovenia. Solvenian Journal of Public Health. 2017;56(4):268-75.

29. Rahman M, Nasrin SO, Rahman M, Rahman A, Mostofa G, Jesmin SS, et al. Maternal pregnancy intention and its association with low birthweight and pregnancy complications in Bangladesh: Findings from a hospital-based study. International Health. 2019;11(6):447-54.

30. Karataşlı V, Kanmaz AG, İnan AH, Budak A, Beyan E. Maternal and neonatal outcomes of adolescent pregnancy. Journal of Gynecology Obstetrics and Human Reproduction. 2019;48(5):347-50.

31. Macedo TCC, Montagna E, Trevisan CM, Zaia V, de Oliveira R, Barbosa CP, et al. Prevalence of preeclampsia and eclampsia in adolescent pregnancy: A systematic review and meta-analysis of 291,247 adolescents worldwide since 1969. European Journal of Obstetics Gynecology and Reproductive Biology. 2020;248:177-86.

32. Melesse DY, Mutua MK, Choudhury A, Wado YD, Faye CM, Neal S, et al. Adolescent sexual and reproductive health in sub-Saharan Africa: Who is left behind? BMJ Global Health. 2020;5(1):e002231.

33. Brown E, Gul X, Abbas A, Nasar A, Balal A. Men's perceptions of child-bearing and fertility control in Pakistan: Insights from a PEER project. Culture, Health \& Sexuality. 2017;19(11):1225-38.

34. Ahonsi B, Fuseini K, Nai D, Goldson E, Owusu S, Ndifuna I, et al. Child marriage in Ghana:
Evidence from a multi-method study. BMC Womens Health. 2019 ;19(1):126.

35. Lo CKM, Tung KTS, Chan KL, Yip PSF, Lau JTF, Wong WHS, et al. Risk factors for child physical abuse and neglect among Chinese young mothers. Child Abuse \& Neglect. 2017;67:193-206.

36. Efevbera Y, Bhabha J. Defining and deconstructing girl child marriage and applications to global public health. BMC Public Health. 2020;20.

37. Abera M, Nega A, Tefera Y, Gelagay AA. Early marriage and women's empowerment: The case of child-brides in Amhara National Regional State, Ethiopia. BMC International Health and Human Rights . 2020;20.

38. Osamor P, Grady C. Factors Associated with women's health care decision-making autonomy: Empirical evidence from Nigeria. Journal of Biosocial Science. 2018;50(1):7085.

39. Neal S, Stone N, Ingham R. The impact of armed conflict on adolescent transitions: A systematic review of quantitative research on age of sexual debut, first marriage and first birth in young women under the age of 20 years. BMC Public Health. 2016;16.

40. Zaman M, Koski A. Child marriage in Canada: A systematic review. PLoS ONE. 2020;15(3).

41. DeLong SM, Brooks MI, Aliou S, Lundgren R, Corneliess C, Johns NE, et al. Married very young adolescent girls in Niger at greatest risk of lifetime male partner reproductive coercion and sexual violence. PloS One. 2020;15(4):e0231392.

42. Gage AJ. Association of child marriage with suicidal thoughts and attempts among adolescent girls in Ethiopia. Journal of Adolescent Health. 2013;52(5):654-6.

43. Lebni JY, Solhi M, Fard Azar FE, Farahani FK. Qualitative study of social determinants of child marriage in Kurdish regions of Iran: Evidence for health promotion interventions. Journal of Education and Health Promotion. 2020;9:242. 